\title{
Data-Privacy Concerns and Its Influence on Consumer Purchasing Intention in Bangladesh and India
}

\author{
Sharjana Alam Shaily ${ }^{1}$ \\ ${ }^{1}$ University of Leeds, UK \\ Correspondence: Sharjana Alam Shaily, Leeds Business School, University of Leeds, UK. E-mail: \\ Sharjana16@gmail.com
}

Received: November 30, 2020

Accepted: December 31, $2020 \quad$ Online Published: January 28, 2021

doi:10.5539/ijms.v13n1p26

URL: https://doi.org/10.5539/ijms.v13n1p26

\begin{abstract}
The research studies the factors of customers' awareness of their online behavior. This paper aims to highlight the gaps in customer awareness and views regarding data privacy, marketing research, and factors that impact the purchasing intentions in developing nations like India and Bangladesh. Previously it can be seen that there has been much research done in this area, but mostly those were for developed nations. However, in developing nations, like Bangladesh and India, which are outstanding and growing markets for online marketers, the concept of data privacy is not observed meticulously. Descriptive, relational, and quantitative research methodologies were applied for the study. Inferential statistics via SPSS were used to accomplish the purpose of the research. The target population was infinite, and the sampling frame was focused on Bangladesh and India's internet users. 440 respondents were approached, and the received response rate was close to $81 \%$, 354 responses. Unlike this study, commonly explorative and qualitative research methodologies were considered for similar research before. The research outcomes demonstrate that consumers in Bangladesh and India are mindful of data privacy, and the result of this research supports the current literature. The outcomes showed a significant positive relationship between the consumers' view of how online platforms of companies handle their data with their buying intentions. Nevertheless, in these recommended relationships from the framework, customer commitment's moderating influence plays a significant role in forming buying intention. The research is particularly important for marketing professionals to understand customers' expectations from the companies regarding customize marketing. This research envisioned to cause some influence the literature and executive implications with development of a new research framework, adjusting new variables, and hypotheses, which were solely based on keeping in mind, the customers of Bangladesh and India.
\end{abstract}

Keywords: online data privacy, perceived privacy concerns, customized marketing, consumer purchasing intention, customer commitment

\section{Introduction}

With growing concern for individuals' cyber protection and privacy, the degree to which online users believe their online privacy is compromised must be understood. According to researchers, companies should keep themselves continuously updated and make them available through their websites to people (Wirtz, Williams, \& Lwin, 2007). But is the policy adequate to address consumers' privacy concerns? Customized marketing is becoming more common in Western media; many companies consider customized advertising more effective. Many organizations claim that personalized advertisements have a detrimental effect on the market due to increased awareness of privacy (Tsai, Egelman, Cranor, \& Acquisti, 2011). This research looks at the influence of customized advertisement and the perceived risk of online information disclosure on consumer perceptions of data privacy protection. The results demonstrate whether data privacy affects purchase trends in developing countries such as Bangladesh and India. The study also focuses on the influence of personalized ads and the professed threat of information revelation on the internet on consumer insight concerning data privacy protection. The outcome is to demonstrate if data privacy affects buying patterns in developing nations like Bangladesh and India. 


\section{Literature Review}

\subsection{Marketing Research Strategies and Techniques}

Conducting useful marketing research can provide the required chances for applying an effective marketing campaign, leading to an upsurge in sales. Through this research, marketers should discover methods to influence and encourage consumers to buy products with their unique promotion scheme. Organizations can sometimes collect customers' personal information unlawfully for their profit (Jara, Vyt, Mevel, Morvan, \& Morvan, 2018). In marketing research, ethical consideration must be existent throughout. In a report of 1998 of The Federal Trade Commission (FTC), it is stated that $92 \%$ of the websites collect personal data of customers for additional promotional purposes. Because of the one-to-one promotion recently, the businesses and advertising organizations have an extremely high claim for personal information. Knowing the probable immoral matters of marketing research can help them go for better choices (Gupta \& Chennamaneni, 2018).

\subsection{Privacy on the Internet}

The security of a person's private data is the key emphasis of the Internet's confidentiality perception. Most of the time, the online platforms are intended to be manageable, to provide the users with a custom-made understanding. To provide this understanding, they go through the online activity of the users and collect individual data. In short, most of the tailored internet activity is founded on individual data (Aguirre, 2015). The organizations that generally runoff by collecting the users' data must be clear to the users about their way of gathering information and using it. Therefore, many organizations have a privacy policy on their website to continue being transparent with the consumers and offer them a brief impression of the motive behind collecting their data. Many of these websites collect data for free. Nevertheless, consumers are most likely paying with individual data. Yet, it can be identified that a lot of individual data which is collected and applied in several commercial resolves can be found all over the Internet (Stouthuysen, Teunis, Reusen, \& Slabbinck, 2018).

\subsection{Factors in Online Data Privacy-Focused Marketing Research}

An examination of the present literature covers several causes within the restraints of online data privacy intensive marketing, such as customized marketing, marketing research, privacy calculus, and online confidentiality. The study investigates prevailing literature on consumer remarks concerning (Chellappa \& Shivendu, 2010). By applying consumers' data, businesses are effectively introducing more tailored promotions (Cox, 2009). The researcher will try to bring the essential factors of data privacy concerns that influence the consumers. This research part will primarily emphasize the research problem and extend the understanding base over the use of factors collected from some previous frameworks and noticeable theories adjacent to data privacy concerns/protection and issues that both, consumer, and the business, may face.

The main variables that were recognized as relevant from the past studies for this research are provided in the table below. The conceptual framework and additional discussion of the study are based on the variables stated below. 
Table 1. Main identified factors/variable from previous literature

\begin{tabular}{|c|c|c|c|c|}
\hline Variables & Definition & Items/Measures & $\begin{array}{l}\text { Underlying Theoretical } \\
\text { Framework }\end{array}$ & Reference \\
\hline Trusting Beliefs & $\begin{array}{l}\text { Trusting beliefs has been defined as 'the } \\
\text { degree to which people believe a firm is } \\
\text { dependable in protecting consumers' } \\
\text { personal information.' }\end{array}$ & $\begin{array}{l}\text { a. Trust } \\
\text { b. Trusting Beliefs }\end{array}$ & $\begin{array}{l}\text { IUIPC framework } \\
\text { Conceptual Framework by } \\
\text { Whang and Im }\end{array}$ & $\begin{array}{l}\text { Malhotra, Kim, and } \\
\text { Agarwal, } 2004 \\
\text { Whang and Im, } 2018\end{array}$ \\
\hline Customization & $\begin{array}{l}\text { To organize products and services as per } \\
\text { consumer requirements. Customization } \\
\text { can be a huge benefit. }\end{array}$ & $\begin{array}{l}\text { a. Use of } \\
\text { Personalization } \\
\text { b. Tailoring the } \\
\text { advertisement }\end{array}$ & $\begin{array}{l}\text { Theoretical framework by } \\
\text { Gerdman and Nordqvist } \\
\text { The framework of } \\
\text { intrusiveness from } \\
\text { customized ads }\end{array}$ & $\begin{array}{l}\text { Gerdman and } \\
\text { Nordqvist, } 2017 \\
\text { Van Doorn and } \\
\text { Hoekstra, } 2013\end{array}$ \\
\hline $\begin{array}{l}\text { Perceived Risk } \\
\text { of Information } \\
\text { Disclosure }\end{array}$ & $\begin{array}{l}\text { According to former research, customer } \\
\text { loyalty to a brand can be made by being } \\
\text { transparent. It makes consumers feel more } \\
\text { connected to the brand. }\end{array}$ & $\begin{array}{l}\text { a. Risk of sharing } \\
\text { data online }\end{array}$ & $\begin{array}{l}\text { Privacy Calculus model } \\
\text { Information Boundary } \\
\text { Theory }\end{array}$ & $\begin{array}{l}\text { Chen, } 2018 \\
\text { Morey, Forbath and } \\
\text { Schoop, } 2015\end{array}$ \\
\hline $\begin{array}{l}\text { Perceived } \\
\text { Usefulness }\end{array}$ & $\begin{array}{l}\text { Perceived usefulness is the degree to } \\
\text { which an individual thinks that giving out } \\
\text { their data to an information system may } \\
\text { help. }\end{array}$ & $\begin{array}{l}\text { a. Benefits of sharing } \\
\text { data online } \\
\text { b. Benefits of } \\
\text { customization }\end{array}$ & $\begin{array}{l}\text { Theoretical framework by } \\
\text { Gerdman and Nordqvist } \\
\text { Technology acceptance } \\
\text { model } \\
\text { Privacy Calculus model }\end{array}$ & $\begin{array}{l}\text { Gerdman and } \\
\text { Nordqvist, } 2017 \\
\text { Xu, Luo, Carroll and } \\
\text { Rosson, } 2011 \\
\text { Chen, } 2018\end{array}$ \\
\hline $\begin{array}{l}\text { Perceived Data } \\
\text { Privacy } \\
\text { Protection }\end{array}$ & $\begin{array}{l}\text { Data protection or information privacy } \\
\text { refers to the link between gathering and } \\
\text { using individual data of a person. }\end{array}$ & $\begin{array}{l}\text { a. Data privacy } \\
\text { concerns } \\
\text { b. Data privacy } \\
\text { protection policies }\end{array}$ & $\begin{array}{l}\text { Information Boundary } \\
\text { Theory }\end{array}$ & $\begin{array}{l}\text { Park, Liu, and } \\
\text { Headrick, } 2020\end{array}$ \\
\hline $\begin{array}{l}\text { Customer } \\
\text { Commitment }\end{array}$ & $\begin{array}{l}\text { Customer commitment refers to an } \\
\text { obligation to buy the same product and } \\
\text { use the same company, also referred to as } \\
\text { customer loyalty. }\end{array}$ & $\begin{array}{l}\text { a. Commitment } \\
\text { b. Loyalty }\end{array}$ & $\begin{array}{l}\text { A model of consumers' } \\
\text { evaluation of unethical } \\
\text { marketing behavior. }\end{array}$ & $\begin{array}{l}\text { Skinner and Taylor, } \\
2005 .\end{array}$ \\
\hline $\begin{array}{l}\text { Consumers' } \\
\text { Purchasing } \\
\text { Intention }\end{array}$ & $\begin{array}{l}\text { Purchase intention refers to the } \\
\text { enthusiasm of a consumer to buy a } \\
\text { particular service or product. Several } \\
\text { internal and external factors have a } \\
\text { substantial impact on purchasing } \\
\text { intention. }\end{array}$ & $\begin{array}{l}\text { a. Behavioral } \\
\text { intention } \\
\text { b. Buying intention }\end{array}$ & $\begin{array}{l}\text { Theoretical framework by } \\
\text { Gerdman and Nordqvist } \\
\text { Trust-based consumer } \\
\text { decision-making model }\end{array}$ & $\begin{array}{l}\text { Gerdman and } \\
\text { Nordqvist, } \\
2017 \\
\text { Kim, Ferrin, } \\
\text { and Rao, 2007 }\end{array}$ \\
\hline
\end{tabular}

\subsection{Hypotheses Development}

The hypotheses development section will help create the research framework and the arguments behind each hypothesis's formulation. Table 3 under section 4.5 shows how the following constructs were measured. Please refer to that.

\subsubsection{Influence of Trusting Beliefs on Perceived Risk}

Trusting beliefs have a direct impact on risk beliefs. For instance, Whang and Im (2018) debated about the decrease of trust "the perceived uncertainty and hence the perceived vulnerability". If put otherwise, then the trusting beliefs are estimated to moderate the perceptions of risk. In a cross-cultural web-based retailing study, Coffey and Kabadayi (2020) found that risk perception has been negatively affected by trusting beliefs. The more trust a customer has in an online firm, the more improbable they are to predict the hazard in giving individual data to the firm (Malhotra, Kim, \& Agarwal, 2004). Hence, according to the previous research of Malhotra, Kim and Agarwal (2004), the following hypothesis is appropriate for this study:

H1: Trusting beliefs are negatively related to the perceived risk of information disclosure.

\subsubsection{Influence of Customization on Perceived Usefulness}

As Jackson (2007) recommends, personalization techniques should be a part of companies' overall marketing strategy. According to the suggestions of Zhang and Zhang (2013), marketers need to redesign core competitiveness by functioning to a consumer-centric model from the product-centric model. Subsequently, companies need to rely upon a more personalized approach towards customers for sustaining longer in the industry. Gerdman and Nordqvist (2017) assume that the parts of 'Perceived usefulness' and 'Perceived intrusiveness' will straightforwardly influence the subjects' perspectives towards customized ads. The perceived usefulness has been adapted to this study in the sense of users' perceptions. This leads to the second hypothesis of this research, that is,

H2: Customization has a positive relationship with perceived usefulness. 


\subsubsection{Influence of Perceived Risk and Usefulness on Perceived Data Privacy Protection}

The rapid development of the internet and a rising number of customers worry about their data privacy protection, which is an outcome of internet development and e-commerce. Moreover, this condition has intensified the issue and made privacy risk a significant factor to worry about for both the marketers and consumers. Such activities can harm consumer perceived data protection towards any organization and increase their concern for data privacy. This can direct towards consumer fear in affiliation to wrong utilization of their data. Therefore,

H3a: Perceived risk of information disclosure negatively impacts consumer perception towards data privacy protection.

Nonetheless, on the other hand, it can be observed from the previous literature that if the consumers find disclosure of personal information to be useful, then they would instead appreciate that. The consumers think of it as less intrusive if they see the ads are relevant to them (Gerdman \& Nordqvist, 2017). According to José García and Juan's (2009) suggestion, in the case of online trading, ease of use, usefulness, and perceived trust is very necessary. Later, Hossein and Fateme (2012) confirmed the significant positive connection among consumers' behavior towards perceived use, perceived credibility, and perceived data privacy protection of an organization. Hence, hypothesis H3(b) was formed.

H3b: Perceived usefulness of customization will have a positive effect on perceived data privacy protection.

As a result, taking both the independent variables into consideration, $\mathrm{H} 3$ can be formed, making H3a and H3b as its underlying hypotheses:

H3: Perceived risk of information disclosure and perceived usefulness both significantly impact perceived data privacy protection.

\subsubsection{Relationship of Perceived Data Privacy Protection on Purchasing Intention}

Numerous researchers have discovered verification for an undesirable influence of confidentiality distresses, for example, mobile advertising and client faithfulness programs (Demoulin \& Zidda, 2009; Zhao et al., 2012). Tsai et al. (2011), for instance, discovered that clients are also keen to pay a better price to buy commodities from websites which they believe protect their data. Their study reveals that clients are careful of the financial value of their information. Perceived information privacy protection builds a complete sensitivity and faithfulness for any organization, which may have an uninterrupted influence on their buying choice. Privacy concerns are an imperative variable in several choices concerning the delivery of data, Therefore,

H4: Perceived data privacy protection has a significantly strong correlation with consumers' purchasing intention.

2.4.5 Moderator Effect of Customer Commitment on the Influence of Perceived Data Privacy Towards Purchasing Intention

As associations between organizations and clients become progressively imperative, customer commitment is needed to create long-lasting and effective relationships. Customer commitment has been explained as the attachment of any person to a company. Additionally, this is theoretically comparable to customer reliability and participation (Yusfi, Harrigan, Soutar, \& Daly, 2018). Supplementary, client commitment has been demonstrated to affect the clients' assessment procedure (Jara et al., 2018), causing tactical benefits, for instance, uninterrupted investment, bigger word-of-mouth, and faithfulness. The current study additionally implies that the function of commitment in an assessment judgment should be taken into consideration, as committed clients may be more lenient in their judgments. Based on the literature, it is hypothesized that:

H5: Customer commitment has a moderation effect on the influence of perceived data privacy towards consumer purchasing intention

\section{Conceptual Framework}

Previous studies relating to this research topic mostly took a qualitative approach, unlike this research. Even though all the below conceptual model variables have been important parts of existing data privacy literature and some of the relationships have already been tested, those studies were done by different authors for different purposes. The conceptual model for this research has been built keeping the consumers of developing nations in mind, which has not been explored much. Moreover, privacy concerns previously were treated as an external variable in the theoretical framework by Gerdman and Nordqvist (2017), whereas this research is trying to examine perceived data privacy protection as one of the main variables that could lead to purchasing intention. Also, the variable customer commitment from the model of 'Consumers' evaluation of unethical marketing behavior and Equity theory' (2019), has been added as a moderator. These relationships between trusting beliefs 
(Malhotra, Kim, \& Agarwal, 2004), perceived risks of data disclosure (Xu et al., 2011), perceived usefulness (Gerdman \& Nordqvist, 2017) of customization, and perceived data privacy protection (Park, Liu, \& Headrick, 2020) leading to consumer purchase intention (Kim, Ferrin, \& Rao, 2007) and the effect of customer commitment on them have never been tested before. As a result, this new conceptual framework presents three out of five new hypotheses and studies all the variables in one sole framework.

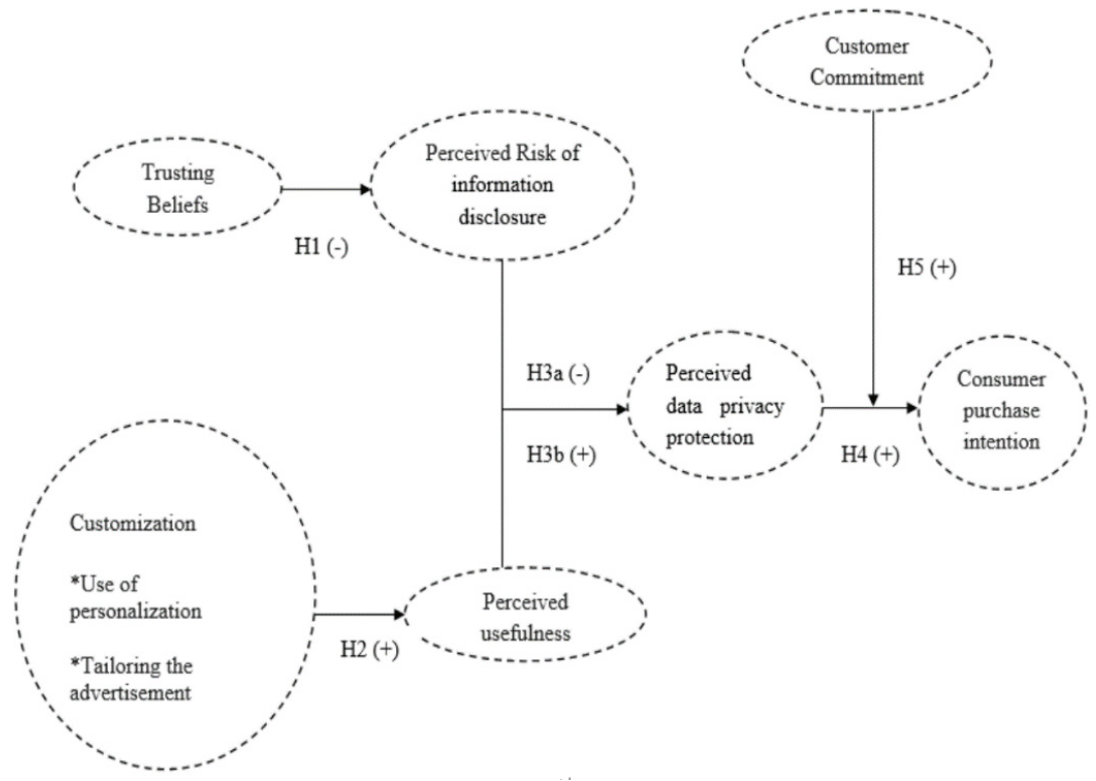

Figure 1. Conceptual framework

\section{Research Methodology}

The most suitable research method for this study was to go for surveys. In survey research, questionnaires were given to the applicants. The answers were clarified in the later parts of the dissertation. The questionnaire was required to be appropriately built to conduct a valid and trustworthy survey. The study can also be said to contain interpersonal research as it does contain testable hypotheses. The interactive study technique is applied when a study observes the connection between two or more variables (Bryman \& Bell, 2007). The non-probability sampling method was used as the respondents had to be internet users of Bangladesh and India. However, due to the questionnaire only sent to the researcher's known people, there is a higher risk of sampling bias. The questionnaire was distributed mainly via social media. The questionnaire is available in the Appendix. Below Table 2 mentions the applied research methods for this study. An elaborate discussion on the research and sampling methods has been given in the later parts.

Table 2. Applied research methods for this study

\begin{tabular}{ll}
\hline Research Philosophy: & Interpretivist \\
\hline Research Design: & Descriptive and Relational Research Method \\
Secondary Research Strategy: & Books, Articles, and Academic Journals \\
Primary Research Strategy: & Survey Method \\
Research Approach: & Deductive Approach (Quantitative Approach) \\
Sampling Design: & Non-Probability Convenience Sampling - Sample Size 354 \\
Data Analysis Method: & Quantitative Analysis with SPSS \\
\hline
\end{tabular}

\subsection{Research Approach}

This research implemented a deductive approach. The study focused on a quantitative study analysis to collect the original data by using surveys. The close-ended nature of questions in the survey allows a simplified stream of data from Bangladesh and India (Yin, 2007). 


\subsection{Sampling Design}

\subsubsection{Target Population}

Due to the nature of the study, the respondents for this study had to be only Bangladeshi and Indian. The target population was infinite, and they were from a different background (intellectually, skillfully, or living in any nation). However, time, budget, and traveling constraints limited the survey to only the researcher's known people from the stated two countries in social media.

\subsubsection{Sampling Technique}

The non-probability convenience sampling method was considered for this paper. In this method, the likelihood of choosing respondents is unplanned, not established, or unfamiliar. Convenience sampling took place for the study as the information was gathered from a target population available to the researcher (Hair, Black, Babin, \& Anderson, 2018). This is a very cost and time-effective method; however, the technique can be disapproved because selection biases and the target group are comparable. The subjects were selected from the connection the research has in social media like Facebook, LinkedIn, Instagram, and WhatsApp.

\subsubsection{Sampling Size}

440 respondents were approached, and the received response rate was close to $81 \%$. The study's ultimate sample size was 354; according to Speklé and Widener (2018), a sample size of 300 is good and has been approved by several other researchers.

\subsection{Questionnaire Design and Testing}

As a tool for gathering data, a survey questionnaire was established (Hiar et al., 2018). The questionnaire contained 18 questions, generally primarily asking about the variables stated in the conceptual framework. A seven pointer Likert scale was used to measure those seven items, extending from 1 to 7, where 1 signifies "Strongly Agree" while 7 signifies "Strongly Disagree". Nevertheless, apart from those 18, there were 5 further demographic questions, out of 4 questions were asked as multiple-choice questions, and 1 question linked to knowing their nationality was open-ended. The questionnaire was pre-tested among 10 separate respondents. A set of alterations were made in the questionnaire based on the pre-test results.

\subsection{Data Analysis Methods}

For evaluating the data, quantitative methods were used. The respondents' summary is given in the next chapter. For assessing the assessment data, several IBM SPSS (version 24 and 25) measurements like Bivariate Regression analysis, Multiple Regression Analysis, Correlation analysis, Regression-based Moderator analysis using PROCESS macro v3.1 by Andrew F. Hayes and Reliability Analysis (to check the inner steadiness and reliability of the questionnaire, validated by Cronbach alpha) were used for this research. Furthermore, Anova was carried out to check one demographic question, even though it is not part of the established hypotheses. 
Table 3. Analytical method and reasoning behind using them for hypotheses testing

\begin{tabular}{|c|c|c|}
\hline Analytical methods & Hypotheses & Purpose \\
\hline Bivariate Regression Analysis & $\mathrm{H} 1$ and $\mathrm{H} 2$ & $\begin{array}{l}\text { This analysis involves two variables (outlined in } \mathrm{H} 1 \\
\text { and } \mathrm{H} 2 \text { ), for determined the empirical relationship } \\
\text { between them (Pallant 2013) }\end{array}$ \\
\hline Multiple Regression Analysis & $\mathrm{H} 3$ and $\mathrm{H} 3 \mathrm{~b}(\mathrm{H} 3)$ & $\begin{array}{l}\text { Testing the degree of influence between two } \\
\text { independent variables (perceived risk and usefulness) } \\
\text { on the dependent variable (perceived data privacy } \\
\text { protection) }\end{array}$ \\
\hline Correlation Analysis & $\mathrm{H} 4$ & $\begin{array}{l}\text { Correlation analysis was done to see the relationship } \\
\text { between the two variables (perceived data privacy } \\
\text { protection with consumer purchasing intention) }\end{array}$ \\
\hline $\begin{array}{l}\text { Moderator analysis using } \\
\text { PROCESS macro v } 3.1 \text { by Andrew } \\
\text { F. Hayes }\end{array}$ & H5 & $\begin{array}{l}\text { This test was done to see if there is any moderating } \\
\text { effect of customer commitment to the relationship } \\
\text { between (perceived data privacy protection and } \\
\text { consumer purchasing intention) }\end{array}$ \\
\hline Oneway Anova test & $\begin{array}{l}\text { The null hypothesis }(\mathrm{H} 0) \text { states that there is no } \\
\text { difference in how Indian and Bangladeshi } \\
\text { customers who lived in a developed nation for } \\
\text { more than a year perceive data privacy while } \\
\text { shopping online compared to those who did } \\
\text { not. } \\
\text { H0: There is no effect/relationship between the } \\
\text { factor and whether the customers live in any } \\
\text { developed nation for more than a year. } \\
\text { H1: There is a relationship. } \\
\text { Factor: Perceived data privacy protection } \\
\text { Group 1: Lived in developed a nation more } \\
\text { than a year } \\
\text { Group 2: Did not }\end{array}$ & $\begin{array}{l}\text { This test was done not because of any hypothesis } \\
\text { formation. Still, the study tried to demonstrate the } \\
\text { difference in the perception of the variable data } \\
\text { privacy protection between two groups by comparing } \\
\text { their means, one who lived in a developed nation for } \\
\text { than a year and the other who did not. This was } \\
\text { mostly done to check the differences in awareness } \\
\text { among the customers as in the developed nation as } \\
\text { data privacy is a much-discussed topic in those } \\
\text { countries. }\end{array}$ \\
\hline
\end{tabular}

\subsection{Ethical Consideration}

The ethical difficulties connected with marketing research activities are very vital for the researcher to respect. The study gathered only those secondary data for which there was authorization. While gathering primary data, it was ensured that only those unnamed responses were logged, which the respondents were permitted to use. All the data collected in this study are firmly for research and learning purposes (Chesser, Porter, \& Tuckett, 2020).

\section{Data Analysis and Results}

\subsection{Content Analysis}

Active May 25th, 2018, the General Data Protection Regulations (GPDR) were put to action by the EU. The key target of applying this rule was to keep the people safe in terms of guarding their data (Hossain \& Khondoker, 2018). Through applying this law, the question might raise about the new GPDR influencing the nations like India and Bangladesh, who are trading allies of the EU.

Corporations like Facebook have been collecting data from Android devices like SMS and call records for years. There have been numerous objections from many Twitter users that there are data of call history of months and years in the downloadable Facebook data unit (Warren, 2018). People connected with the third-party claims to their Facebook or other accounts may have unintentionally provided the authority to access their data. Google also pointed out that its rules do not go against the practice. When linking an email account with other third-party requests, people are typically asked to allow specific consents that generally hold the ability to send, read, and delete messages from email.

In nations like India and Bangladesh, there is a vast consumer base for online marketing. The organizations' rules and guidelines will have a vast influence nationwide and worldwide (Carson, 2013). Likewise, many global and local organizations, who are functioning their business in nations like this, have been directing many general practices regarding data privacy that may or may not be considered moral in many cases. Moreover, in many circumstances, the consumers are entirely not mindful of these immoral practices (Boerman, Kruikemeier, \& Borgesiu, 2017). 


\subsection{Respondent Profile Analysis}

Respondents' nationality is required to be from both Bangladesh and India. The other demographic features are offered in the below table. From the table below, 74.01 people belong to the age group of $18-28$, and $87.85 \%$ of the respondents at least did their bachelor's. This certainly does not signify a close-by state for the people of Bangladesh or India. This is one of the restraints for this research, which was affected due to the convenience sampling technique.

Table 4. Respondents profile

\begin{tabular}{ll}
\hline Demographics & Percentage \% \\
\hline Gender: & \\
Male & 55.93 \\
Female & 42.66 \\
Prefer not to say & 1.41 \\
Total & \\
Age Category: & \\
18-28 & 74.01 \\
$29-39$ & 18.64 \\
$40-50$ & 4.52 \\
$51+$ & 2.82 \\
Total & \\
Educational Background: & \\
High School & 12.15 \\
Bachelors & 48.31 \\
Masters & 34.46 \\
PhD & 1.98 \\
Prefer not to say & 3.11 \\
Total & \\
\hline
\end{tabular}

\subsection{Reliability Analysis}

IBM SPSS, 25th version was used to estimate the reliability of the conducted survey. To inspect the reliability coefficient, Cronbach's alpha reliability test was conducted. The Reliability analysis is significant to test and check the scales' interior stability in the survey (Malhotra, 2009). By taking the total sample of the study, the reliability has been measured. The reliability test exposed the Cronbach alpha's value for the seven concepts of this study to range from a minimum of .671 to a maximum of .782. Even though it is better to have an alpha value more than .07 (Pallant, 2013), however, Malhotra (2009) claims that the scales are still considered reliable if there are alpha values of .06 or above. Thus, all the scales are found to be reliable and internally constant for this study. The Cronbach Alpha outcomes of the variables are presented in the table below:

Table 5. Cronbach Alpha analysis outcomes

\begin{tabular}{lll}
\hline Construct used & Cronbach's Alpha & Number of Items \\
\hline Trusting Beliefs & .753 & 3 \\
Customization & .782 & 2 \\
Perceived Risk of Information & .671 & 2 \\
Disclosure & & \\
Perceived Usefulness & .714 & 2 \\
Perceived Data Privacy & .682 & 4 \\
Protection & & \\
Customer Commitment & .718 & 2 \\
Consumer Purchasing & .680 & 3 \\
Intentions & & \\
\hline
\end{tabular}

\subsection{Anova Analysis Within Two Groups}

An ANOVA test was carried out by associating the means to see if there is a variance among the groups in identifying data confidentiality protection online based on them living in developed countries. Group 1 lived in a developed nation for more than a year, and group 2 did not. As the importance in the consistency, the table is less than .05 (at $\mathrm{p}<.001$ ), and the Welch value is significant at $\mathrm{p}<.001$ from the robust table. It says a noteworthy dissimilarity among the two groups on how they identify online data privacy protection. $41.53 \%$ of the respondents 
said yes, and $58.47 \%$ said no to this question. Therefore, rejecting the null hypothesis and accepting the alternative hypothesis that there is an effect/relationship on how customers perceive data privacy originally from India and Bangladesh but lived in a developed nation for more than a year.

\subsection{Hypothesis Testing (via SPSS)}

Bivariate and multiple regression analyses have been applied for $\mathrm{H} 1, \mathrm{H} 2, \mathrm{H} 3 \mathrm{a}$, and $\mathrm{H} 3 \mathrm{~b}(\mathrm{H} 3)$. Correlation analysis for H4 and Regression-based Moderator analysis using PROCESS macro v3.1 by Andrew F. Hayes for H5. Seven main variables have been derived from the items under five critical concepts of the conceptual framework. In the following segments, the results of all the hypotheses tests are offered.

H1: Trusting beliefs are negatively related to the perceived risk of information disclosure.

Bivariate Regression analysis is done to assess the link between one independent variable with the dependent variable. The table below offers outcomes that show the results of the bivariate regression analysis of the above-stated hypotheses H1. R Square of .369 shows a good correlation (even if not high) between the predictor variables and the criterion variables. A significant model emerged $(\mathrm{F} 1,353=206.812, \mathrm{p}<.0001)$. Adjusted $\mathrm{R}$ square $=.368$. Beta value of $-.608, .117$ indicates that there is a negative correlation between the variables. From the outcome results, the higher the trusting beliefs, the lower will be the perceived risk of information disclosure and vice versa. Results support the hypothesis as the significance score of .000 shows that the association is significant at $\mathrm{p}<.01$ (Palihawadana, 2017).

$\mathrm{H} 2$ : Customization has a positive relationship with perceived usefulness.

Another Bivariate regression analysis is done for H2. The table below represents the results. R Square of .606 shows a high correlation between the predictor variables and the criterion variables. A significant model emerged $(\mathrm{F} 1,353=542.234, \mathrm{p}<.0005)$. Adjusted $\mathrm{R}$ square $=.605$. A beta value of .778 indicates that there is a strong positive correlation between the variables. Thus, from the outcome of the results, it can be said that Customization has a strong influence on perceived usefulness. Results support the hypothesis as the significance score of .000 shows that the association is significant at $\mathrm{p}<.01$ (Palihawadana, 2017).

H3: Perceived risk of information disclosure and perceived usefulness both significantly impact perceived data privacy protection.

H3a: Perceived risk of information disclosure negatively impacts consumer perception towards data privacy protection.

H3b: Perceived usefulness of customization will have a positive effect on perceived data privacy protection.

Multiple Regression analysis is a suggested test to do when multiple independent variables measure the one dependent variable (Palmatier, Houston, \& Hulland, 2018). The table below provides results that signify multiple regression analysis outcomes of the above-mentioned hypotheses $\mathrm{H} 3$ and its underlying hypotheses (H3a and $\mathrm{H} 3 \mathrm{~b}$ ) A significant model emerged $(\mathrm{F} 2,352=216.103, \mathrm{p}<.0005)$. Adjusted R square $=.549$. Both the independent variables have a strong impact on the dependent variable (perceived data privacy protection). However, as stated in the hypotheses, perceived risk negatively impacts, whereas perceived usefulness has a positive impact. Thus, supporting the main and underlying hypotheses.

H4: Perceived data privacy protection has a significantly strong correlation with consumers' purchasing intention.

Simple correlation analysis was done here to see if there is any relationship between the perceived data protection with purchasing intention of the consumers living in Bangladesh and India. As there is a significance at $\mathrm{p}<.01$, it shows a positive relationship between the two variables. However, as the Pearson Correlation value is .608, which is neither extremely high nor low, it can be said the relationship is an average to high between these two. The below has emerged:

Table 6. Correlation analysis

\begin{tabular}{llll}
\hline & & Data protection & Purchase intention \\
\hline Data protection & Pearson Correlation & 001 & $.620^{* *}$ \\
& Sig. (2-tailed) & 355 & .000 \\
& $\mathrm{~N}$ & & 355 \\
Purchase intention & Pearson Correlation & $.620^{* *}$ & 001 \\
& Sig. (2-tailed) & .000 & 355 \\
& $\mathrm{~N}$ & 355 & \\
\hline
\end{tabular}

Note. $* *$ Correlation is significant at that 0.01 level (2-tailed). 
H5: Customer commitment has a moderation effect on perceived data privacy towards consumer purchasing intention.

Regression driven moderator test using Process Macro was run to test this hypothesis (H4). The summary output of $(\mathrm{F} 3,347=133.5788, \mathrm{p}<0.01)$, R square $=0.5359$ was emerged. The output table in appendix $\mathrm{F}$ indicates that the interaction was significant at $(\mathrm{p}<0.01, \mathrm{C} 1=[+0.0717,+0.1602])$.

Customer commitment's moderator effect accounts for $3.5 \%$ of the variation caused by data protection on purchase intention. It was also observed that the interaction effect was significant for the moderate level of commitment at $\mathrm{C} 2=[+0.0705,+0.2974]$ and a high level of commitment at $\mathrm{C} 2=[+0.2235,+0.4391]$. However, at low-level commitment, it was not significant at $\mathrm{p}>0.05 \mathrm{C} 1=[-.1064,+0.1796]$.

\section{Discussion}

The regression and multiple regression analysis results support all the hypotheses (H1, H2, H3a, H3b, and H5). Validated by the Cronbach's alpha coefficient range from a minimum .671 to a maximum .782 for the study's seven concepts, the primary outcomes specify that the research scales were reliable. Thus, it can be said the results do support the research claims of the framework.

\subsection{ANOVA Analysis of the Two Sets of Population}

ANOVA analysis was done to see the variance among the people belonging to the same nation (India and Bangladesh), yet separated into two groups, one who lived in developed countries for more than one year and another who did not. For this study, it was vital to see the variance in perceived data secrecy protection of people residing in developing nations to those who do not. Through the Anova test, it was found that there is a noteworthy dissimilarity at $\mathrm{p}<.01$ among the two groups. After equating the means from the descriptive table, the results showed that consumers of Bangladesh and India who have lived or lived in a developed country for over one year are more mindful about data privacy than those who did not. The reason for this variance could be that they have better consciousness concerning data privacy marketing approaches due to the current news, measures to safeguard data privacy, and the latest application of GDPR in the EU (EU General Data Protection Regulation, 2016). Nevertheless, as the demographic is mostly educated, the variance among the mean is significantly less.

\subsection{Trusting Beliefs and Perceived Risk of Information Disclosure}

Malhotra, Kim, and Agarwal (2004) state in their trust-risk relationship in the IUIPC design that the better the consumers' level of trusting beliefs, the smaller their observed risk in providing their data online. The outcomes of this research also advise that supporting hypothesis 1 . Therefore, with more trusting beliefs for a brand, the more enthusiastic the consumers will be to disclose their information online.

\subsection{Customization and Perceived Usefulness}

According to Christine (2018), access to consumers' individual information offers a better chance to accomplish their demands. The results explain that users are fonder of the idea of tailored search results as it satisfies their requirements (Al-Khalaf \& Choe, 2020). In this situation, the overview of customized promotion can be more operational. It can raise the users' involvement through personalized ads and deals that meet their needs and methods to be more striking, but this can also form a relationship between the users of a third party retrieving their data.

\subsection{Perceived Risk of Information Disclosure, Perceived Usefulness, and Perceived Data Privacy Protection}

The perceived threat of data revelation and perceived efficacy of customization were crucial influences on perceived data privacy protection. On the one hand, perceived risk was adversely linked with perceived data privacy protection, and on the other hand, perceived helpfulness was positive. To inspect the online behavior of consumers in real-time and form appropriate and tailored marketing offers, sellers take the help of the Internet to collect their information (Chan, Ahmad, \& Zaman, 2018). The concern is that the consumers are becoming more alert to the condition. They are more concerned about organizations' access or any third-party corporation to their valued information left behind from the prior online activities. Conversely, the consumers welcome the idea of customization, and they are glad to share their information in return for the benefits they get from customization (Li, Cheng, \& Teng, 2020).

\subsection{Perceived Data Privacy Protection and Consumers' Purchasing Intention}

The relationship with the perceived usefulness of customization was shown to be significant in this study. In the privacy, calculus model outcomes showed a significant relationship between perceived risk of information disclosure and perceived value of information disclosure. This framework tried to examine how this might lead to consumer purchasing intention, and findings show that these two variables have a good correlation at a 
significance level of $\mathrm{p}<.01$. Pearson correlation was at .608. It is said higher the Pearson correlation. There will be stronger correlations between the two variables (Pallant, 2013).

\subsection{Moderating Effect of Customer Commitment}

The moderation of customer commitment significantly influences the strength of the relationship between perceived data privacy protection and consumer purchasing intention. A key finding of importance to marketers, therefore, means that improving the level of customer commitment towards the brand (Chaudhuri \& Holbrook, 2019), will strengthen the relationship between the consumers' level of perceived value and therefore increase the level of consumer willingness to purchase regardless of their perception they have about the companies' data protection policies (Ha \& Perks, 2005). Companies operating in Bangladesh and India should consider the moderating effect and prioritize increasing consumer purchasing intention.

\subsection{Summary of the Findings}

To summarize, it can be said that all the 5 hypothesized associations were reinforced from this research. Overall, these results provide evidence of the relationships between the constructs in the conceptual model, which links consumers' perceived data privacy protection and their purchasing intentions. The moderation effect of customer commitment is significant to the relationships between perceived data privacy protection and purchasing intention. These findings provide valuable insights into online consumer privacy concerns and the role of customization and trusting beliefs in influencing consumers to disclose their personal information.

Table 7. Summary of the hypotheses results

\begin{tabular}{|c|c|c|c|}
\hline & \multicolumn{2}{|c|}{ Hypotheses } & Results \\
\hline H1 & \multicolumn{2}{|c|}{ Trusting beliefs are negatively related to the perceived risk of information disclosure. } & Supported \\
\hline $\mathrm{H} 2$ & \multicolumn{2}{|c|}{ Customization has a positive relationship with perceived usefulness. } & Supported \\
\hline \multirow[t]{3}{*}{ H3 } & \multicolumn{2}{|r|}{$\begin{array}{l}\text { Perceived risk of information disclosure and perceived usefulness both have a significant impact on perceived data privacy } \\
\text { protection. }\end{array}$} & Supported \\
\hline & $\mathrm{H} 3 \mathrm{a}$ & $\begin{array}{l}\text { Perceived risk of information disclosure negatively impacts consumer perception towards data privacy } \\
\text { protection. }\end{array}$ & \\
\hline & $\mathrm{H} 3 \mathrm{~b}$ & The perceived usefulness of customization will have a positive effect on perceived data privacy protection. & \\
\hline $\mathrm{H} 4$ & \multicolumn{2}{|r|}{ Perceived data privacy protection has a significantly strong correlation with consumers' purchasing intention. } & Supported \\
\hline H5 & \multicolumn{2}{|r|}{$\begin{array}{l}\text { Customer commitment has a moderation effect on the influence of perceived data privacy towards consumer purchasing } \\
\text { intention. }\end{array}$} & Supported \\
\hline
\end{tabular}

\section{Conclusion}

This study delivers an understanding of the ethics of Bangladeshi and Indian consumers. As the study scales were dependable, and examinations were all noteworthy, the research claims can be considered further.

It may help marketers show effective marketing platforms and positioning of recent and future online marketing approaches. Nevertheless, in doing so, companies should respect rules, values, and peoples' rights. It can be concluded that internet users are contented with tailored search results as the organizations can simply meet the consumers' requirements and needs (Pandey \& Gudipudi, 2019). As a result, despite all the concepts states concerning confidentiality distresses and what researchers have debated, the result according to this study is that individuals in Bangladesh and India like being seen than being unidentified, and this is a revolutionary result in the era of online advertising and something researchers and promoters should reflect on.

\subsection{Implications}

\subsubsection{Managerial Implications}

If organizations clearly show their purpose of gathering information online, terms, and conditions, it can increase consumers' buying objective. Furthermore, doing so will upsurge their trusting belief concerning the businesses and efficacy of customization in return for their private information (Bleier \& Eisenbeiss, 2015). The conceptual model for this analysis will then be acknowledged. Quite a few proposals can be established from this study. The marketers must be mindful of their limits (Taylor, Ferguson, \& Ellen, 2015). The organizations need to be more transparent to the consumers while collecting data for promotion purposes and preparing them for the future state. These data may be used to send them personalized advertisements (Kim \& Han, 2014). Another important implication would be that managers, along with protecting the consumers' data should match up to their level with the international standards and prioritize increasing the level of customer commitment (Brakus, Schmitt, \& Zarantonello, 2009). 


\subsubsection{Theoretical Implications}

Contributions to Theory: New Framework

Based on the literature review, this study has developed a new model to measure consumer commitment's moderator impact on the relationship between perceived data privacy concerns and its influence on buying choices. Very few studies have measured these variables' effect on interactive objectives (Pengnate \& Sarathy, 2017). Even lesser research was done bearing in mind the customers of developing countries like India and Bangladesh. Additionally, valuable perceptions have been gained from this study in online data privacy and customization.

Contributions to Marketing Practice

The study helps provide a precise understanding of the privacy concerns of online consumers and further information on consumer behavior (Askegaard, Solomon, Bamossy, \& Hogg, 2013). To keep away from losing consumers, marketers need to make the customers feel like they have control over their online use (Morey, Forbath, \& Schoop, 2015).

\subsubsection{Implication for Policy Makers}

Besides the upsurge of digital progress, organizations are wide-ranging up vast data about consumers' activities online. Though limited organizations are available in the segment of their data practices, many of them prefer not to bring their consumers to light (Pires, Stanton, \& Rita, 2006). In this case, the policymakers like the government and law division of Bangladesh and India have vital parts in pledging the data protection for its people. Just like what the EU did by applying GDPR (Bhandari \& Bansal, 2019).

\subsection{Limitations of the Study}

There was a budget limit due to which the sample size was smaller, and most of the respondents were falling under a similar age group and educational background. It can be said that the results and recommended effects of this study requires more work to be definite. An additional limit is that different variables of further importance could also exist (Chung, Liao, \& Fong, 2020).

\subsection{Scope for Future Research}

The key results of this study have delivered plans for various upcoming possible studies. An important opportunity which is provided by this study is to investigate different product or service category or a different context. Cross-cultural international study can also be considered to conduct additional research and figure out if this state of enthusiasm can share individual information to an organization's contrasts among several nations or cultures (Martin, Bohra, \& Palmatier, 2018).

The researcher proposes putting in more demographic sections to figure out the different demography variances for upcoming research. Additionally, considering the EU-legislation issued in 2018 (Dodds-Smith \& Roussanov, 2020) restrictions prompting organizations' behavior online and companies' policies should be considered thoroughly.

\section{Acknowledgments}

There are no grants for this study. This study was originally carried out while the researcher worked on her master's dissertation at the University of Leeds, UK.

\section{Reference}

Aguirre, E. (2015). Unraveling the Personalization Paradox: The Effect of Information Collection and Trust-Building Strategies on Online Advertisement Effectiveness. Journal of Retailing, 91(1), 34-49. https://doi.org/10.1016/j.jretai.2014.09.005

Al-Khalaf, E., \& Choe, P. (2020). Increasing Customer Trust Towards Mobile Commerce in a Multicultural Society: A Case of Qatar. Journal of Internet Commerce, 19(1), 32-61. https://doi.org/10.1080/15332861.2019.1695179

Askegaard, S. T., Solomon, M., Bamossy G., \& Hogg, M. K. (2013). Consumer Behaviour: A European Perspective (5th ed.). Harlow: New York.

Bhandari, R. S., \& Bansal, S. (2019). Privacy Concerns with Social Networking Sites: An Empirical Investigation of Users in National Capital Region (NCR), India. South Asian Journal of Management, 26(3), $68-87$.

Bleier, A., \& Eisenbeiss, M. (2015). The Importance of Trust for Personalized Online Advertising. Journal of Retailing, 91, 390-409. https://doi.org/10.1016/j.jretai.2015.04.001 
Boerman, S. C., Kruikemeier, S., \& Borgesiu, F. J. Z. (2017). Online Behavioral Advertising: A Literature Review and Research Agenda. Journal of Advertising, 46(3), 363-376. https://doi.org/10.1080/00913367.2017.1339368

Brakus, J. J., Schmitt, B. H., \& Zarantonello, L. (2009). Brand experience: What is it? How is it measured? Does it affect loyalty? Journal of Marketing, 73(3), 52-68. https://doi.org/10.1509/jmkg.73.3.52

Bryman, A., \& Bell, E. (2007). Business research methods (2nd ed.). Oxford University Press Inc.: Pearson Education Limited.

Carson, A. (2013). Researchers Publish Study of Indian Privacy Perceptions. [online] Iaorg. Retrieved August 8 , 2020, from https://iaorg/news/a/2012-12-05-researchers-publish-study-of-indian-privacy-perceptions/

Chan, S. W., Ahmad, M. F., \& Zaman, I. (2018). Privacy Perceptions of Online Shopping Behaviour Amongst Malaysian Lazada Online Shoppers. AIP Conference Proceedings, 2016(1), 020036. https://doi.org/10.1063/1.5055438

Chaudhuri, A., \& Holbrook, M. B. (2019). The chain of effects from brand trust and brand affect to brand performance: The role of brand loyalty. Journal of Marketing, 65(2), 81-93. https://doi.org/10.1509/jmkg.65.2.81.18255

Chellappa, R. K., \& Shivendu, S. (2010). Mechanism Design for "Free" but "No Free Disposal" Services: The Economics of Personalization Under Privacy Concerns. Management Science, 56(10), 1766-1780. https://doi.org/10.1287/mnsc. 1100.1210

Chen, H. (2018). Revisiting the Privacy Paradox on Social Media with an Extended Privacy Calculus Model: Revisiting the Privacy Paradox on Social Media with an Extended Privacy Calculus Model. American Behavioral Scientist, 62(10), 1392-1412. https://doi.org/10.1177/0002764218792691

Chesser, S., Porter, M. M., \& Tuckett, A. G. (2020). Cultivating citizen science for all: ethical considerations for research projects involving diverse and marginalized populations. International Journal of Social Research Methodology, 23(5), 497-508. https://doi.org/10.1080/13645579.2019.1704355

Christine, P. (2018). Do Consumers Want to Control Their Personal Data? Empirical Evidence. International Journal of Human-Computer Studies, 110(3), 21-32. https://doi.org/10.1016/j.ijhcs.2017.10.003

Chung, R. Y., Liao, T. F., \& Fong, E. (2020). Data Collection for Migrant Live-In Domestic Workers: A Three-Stage Cluster Sampling Method. American Behavioral Scientist, 64(6), 709-721. https://doi.org/10.1177/0002764220910223

Coffey, S., \& Kabadayi, S. (2020). Consumers' Purchase Intentions of Bi-national Products: Effects of Country-of-Brand, Country-of-Manufacture, and Trusting Beliefs. Journal of Global Marketing, 33(1), 18-33. https://doi.org/10.1080/08911762.2019.1579398

Dodds-Smith, I., \& Roussanov, A. (2020). Duplicate Marketing Authorisations in the EU: Evolution of the Regulatory Framework and Practical Implications. European Pharmaceutical Law Review, 4(3), 142-152. https://doi.org/10.21552/eplr/2020/3/4

Gupta, B., \& Chennamaneni, A. (2018). Understanding Online Privacy Protection Behavior of the Old Adults: An Empirical Investigation. Journal of Information Technology Management, 29(3), 1-13.

Hair, J. F., Black, W. C., Babin, B. J., \& Anderson, R. E. (2018). Multivariate Data Analysis (8th ed.). Cengage Learning, EMEA.

Hossain, K., \& Khondoker, M. (2018). What does GDPR mean for Bangladesh? [online] Dhaka Tribune. Retrieved August 10, 2018, from https://www.dhakatribune.com/opinion/op-ed/2018/07/02/what-does-gdpr-mean-for-bangladesh

Jara, M., Vyt, D., Mevel, O., Morvan, T., \& Morvan, T. (2018). Measuring customers benefits of click and collect. Journal of Services Marketing, 32(4), 430-442. https://doi.org/10.1108/JSM-05-2017-0158

Kim, D. J., Ferrin, D. L., \& Rao, H. R. (2007). A trust-based consumer decision-making model in electronic commerce: The role of trust, perceived risk, and their antecedents. Decision Support Systems, 44(2), 544-564. https://doi.org/10.1016/j.dss.2007.07.001

Kim, Y. J., \& Han, J. (2014). Why smartphone advertising attracts customers: A model of Web advertising, flow, and personalization. Computers in Human Behavior, 33, 256-269. https://doi.org/10.1016/j.chb.2014.01.015 
Li, K., Cheng, L., \& Teng, C. (2020). Voluntary sharing and mandatory provision: Private information disclosure on social networking sites. Information Processing and Management, 57(1). https://doi.org/10.1016/j.ipm.2019.102128

Malhotra, N. K. (2009). Marketing research: An applied approach. Pearson Education. https://doi.org/10.1108/S1548-6435(2009)5

Malhotra, N. K., Kim, S. S., \& Agarwal. J. (2004). Internet users' information privacy concerns (IUIPC): The construct, the scale, and a causal model. Information Systems Research, 15(4), 336-355. https://doi.org/10.1287/isre.1040.0032

Martin, K., Bohra, A., \& Palmatier, R. (2018). Research: A Strong Privacy Policy Can Save Your Company Millions. [online] Harvard Business Review. Retrieved August 5, 2020, from https://hbr.org/2018/02/research-a-strong-privacy-policy-can-save-your-company-millions

Morey, T., Forbath, T., \& Schoop, A. (2015). Customer Data: Designing for Transparency and Trust. [online] Harvard Business Review. Retrieved August 6, 2020, from https://hbr.org/2015/05/customer-data-designing-for-transparency-and-trust

Palihawadana, D. (2015). An Idiot's Guide to SPSS. University of Leeds.

Pallant, J. (2013). SPSS Survival Manual. New York: McGraw-Hill.

Palmatier, R. W., Houston, M. B., \& Hulland, J. (2018). Review articles: Purpose, process, and structure. Journal of the Academy of Marketing Science, 46, 1-5, https://doi.org/10.1007/s11747-017-0563-4

Pandey, N., \& Gudipudi, B. (2019). Understanding 'what is privacy' for millennials on Facebook in India. Journal of Data Protection and Privacy, 2(3), 224-233.

Park, Y., Liu, Y., \& Headrick, L. (2020). When work is wanted after hours: Testing weekly stress of information communication technology demands using boundary theory. Journal of Organizational Behavior, 41(6), 518-534. https://doi.org/10.1002/job.2461

Pengnate, S. F., \& Sarathy, R. (2017). An Experimental Investigation of the Influence of Website Emotional Design Features on Trust in Unfamiliar Online Vendors. Computers in Human Behavior, 67, 49-60. https://doi.org/10.1016/j.chb.2016.10.018

Pires, G. D., Stanton, J., \& Rita, P. (2006). The internet, consumer empowerment and marketing strategies. European Journal of Marketing, 40(9/10), 936-949. https://doi.org/10.1108/03090560610680943

Smith, H. J., Dinev, T., \& Xu, H. (2011). Information Privacy Research: An Interdisciplinary Review. MIS Quarterly, 35(4), 989-1015. https://doi.org/10.2307/41409970

Speklé, R. F., \& Widener, S. K. (2018). Challenging Issues in Survey Research: Discussion and Suggestions. Journal of Management Accounting Research, 30(2), 3-21. https://doi.org/10.2308/jmar-51860

Stouthuysen, K., Teunis, I., Reusen, E., \& Slabbinck, H. (2018). Initial Trust and Intentions to Buy: The Effect of Vendor-Specific Guarantees, Customer Reviews and the Role of Online Shopping Experience. Electronic Commerce Research and Applications, 27, 23-38. https://doi.org/10.1016/j.elerap.2017.11.002

Taylor, J. F., Ferguson, J., \& Ellen, P. S. (2015). From trait to state: Understanding privacy concerns. Journal of Consumer Marketing, 32(2), 77-123. https://doi.org/10.1108/JCM-01-2015-1304

Tsai, J. Y., Egelman, S., Cranor, L., \& Acquisti, A. (2011). The Effect of Online Privacy Information on Purchasing Behavior: An Experimental Study. Information Systems Research, 22(2), 254-268. https://doi.org/10.1287/isre.1090.0260

Van Doorn, J., \& Hoekstra, J. C. (2013). Customization of online advertising. Marketing Letters, 24(4), 339-351. https://doi.org/10.1007/s11002-012-9222-1

Whang, C., \& Im, H. (2018). Does recommendation matter for trusting beliefs and trusting intentions? International Journal of Retail and Distribution Management, 46(10), 944-958. https://doi.org/10.1108/IJRDM-06-2017-0122

Wirtz, J., Williams, J. D., \& Lwin, M. (2007). Consumer online privacy concerns and responses: A power-responsibility equilibrium perspective. Journal of the Academy of Marketing Science, 35(4), 572-585. https://doi.org/10.1007/s11747-006-0003-3

Xu, F., Michael, K., \& Chen, X. (2013). Factors affecting privacy disclosure on social network sites: An integrated model. Electronic Commerce Research, 13(2), 151-168. 
https://doi.org/10.1007/s10660-013-9111-6

Xu, H., Luo, X., Carroll, J. M., \& Rosson, M. B. (2011). The personalization privacy paradox: An exploratory study of decision-making process for location-aware marketing. Decision Support Systems, 51(1), 42-52. https://doi.org/10.1016/j.dss.2010.11.017

Yin, R. (2007). Case study research: Design and methods. Beverly Hills: CA: Sage publishing.

Yusfi, A., Harrigan, P., Soutar, G., \& Daly, T. (2018). Antecedents to Consumer Peer Communication through Social Advertising: A Self Disclosure Theory Perspective. Journal of Interactive Advertising, 18(1), 55-71. https://doi.org/10.1080/15252019.2018.1437854

\section{Appendix A \\ Questionnaire}

\section{Consent Page}

The study aims to analyze consumers' perceptions of developing nations like Bangladesh and India regarding data privacy protection policies. Please take approximately 5 minutes of your time to complete the questionnaire. All responses will be held anonymously and confidentially. The researcher assures that your responses cannot be traced back to you as an individual and are made only for academic research purposes, holds no monetary benefit. Please indicate below that you consent to participate in the study; you understand that you may withdraw at any time; and that you are at least 18 years of age.

If you have any further queries regarding this study, please email the researcher at Sharjana16@gmail.com. Your participation will be highly appreciated. Thank you.

Sharjana Alam Shaily

1. I consent*

\section{Section A}

This section is designed to understand your awareness of data privacy-focused marketing strategies.

1. I am aware of the data privacy-focused marketing practices of the online platforms I like.

1) Strongly Agree 2) Agree 3) Somewhat Agree 4) Neutral 5) Somewhat Disagree 6) Disagree 7) Strongly Disagree

2. I have had a positive experience with online platforms, and I trust them with my data.

1) Strongly Agree 2) Agree 3) Somewhat Agree 4) Neutral 5) Somewhat Disagree 6) Disagree 7) Strongly Disagree

3. I understand the term cookies and what it means while using the internet.

1) Strongly Agree 2) Agree 3) Somewhat Agree 4) Neutral 5) Somewhat Disagree 6) Disagree 7) Strongly Disagree

4. Advertisements custom to my preference increases my overall engagement with the platform.

1) Strongly Agree 2) Agree 3) Somewhat Agree 4) Neutral 5) Somewhat Disagree 6) Disagree 7) Strongly Disagree

5. The online platforms I like to provide many options or setting to protect my data.

1) Strongly Agree 2) Agree 3) Somewhat Agree 4) Neutral 5) Somewhat Disagree 6) Disagree 7) Strongly Disagree

6. Overall, I can trust the terms and conditions of online platforms that I like or use mostly.

1) Strongly Agree 2) Agree 3) Somewhat Agree 4) Neutral 5) Somewhat Disagree 6) Disagree 7) Strongly Disagree

Section B (same scales as section A was followed for this section)

This section is designed to understand your opinion of standard marketing practices regarding data privacy protection.

1. Data privacy protection is essential to me.

2. Personalization of advertisements can help the brands to target the right people. 
3. Companies are collecting my data ethically.

4. In general, I am concerned about my online data privacy.

5. I feel that sharing my data on online platforms is beneficial.

6. I think online platforms are convenient to use.

Section C (same scales as section A was followed for this section)

This section is designed to understand your perception and attitude towards data privacy protection of the companies' online platforms.

1. I am more likely to buy products from the company I am committed to as I trust them more.

2. My perception of a brand affects my purchasing decision.

3. It is very intrusive when I see many ads for particular products that I am not interested in.

4. It would be risky to disclose my personal information, preference, and opinion online.

5. Misuse of my data by online platforms will affect my buying decision.

6. My purchase intention increases if the company provides me with a discount in return for my data.

\section{Section D}

This section is designed to understand your profile.

1. Gender

1) Male 2) Female 3) Prefer not to say

2. Age

1) 18-28 2) 29-39 3) 40-50 4) 51+

3. Nationality

4. Highest Educational level (Currently entrolled or have already completed)

1) High School 2) Bachelors 3) Masters 4) PhD 5) Prefer not to say

5. Have you ever lived-in developing nations more than 1 year?

1) Yes 2) No

\section{Copyrights}

Copyright for this article is retained by the author, with first publication rights granted to the journal.

This is an open-access article distributed under the terms and conditions of the Creative Commons Attribution license (http://creativecommons.org/licenses/by/4.0/). 